\title{
USE OF INTRATHECAL MORPHINE INFUSION FOR SPASTICITY
}

\author{
Luis A. Rogano ${ }^{1}$, Julia Maria Greve², Manoel J. Teixeira ${ }^{1}$ \\ ABSTRACT - Objective: To study the efficacy of intrathecal morphine infusion to treat spasticity. Setting: Functional Neurosurgery \\ Division of University of São Paulo, Brazil. M ethod: Twelve patients with clinical refractory spasticity were studied. Tw o females and \\ 10 males, with median age of 34.4 years (20 to 61 ys.). The initial Ashworth scale was 4.6. They were submitted to pump implanta- \\ tion for intrathecal morphine infusion. Results: The final Ashw orth scale was 2.2. The median dose concentration of Intrathecal \\ morphine was $0.95 \mathrm{mg}$, with a mean frequency of 1.8 times a day. Four patients developed pruritus, two patients nausea, two patients \\ urinary retention, how ever all improved after morphine concentration was decreased. One patient was submitted to pump rewiew \\ after extrusion catheter. Conclusions: Intrathecal morphine infusion is very helpful in patients with spasticity refractory to clinical \\ treatment, and we observed only minor complications.
}

KEY WORDS: spasticity, morphine, intrathecal infusion.

\begin{abstract}
Uso de morfina intratecal para tratamento de espasticidade
RESUM 0 - Objetivo: Estudar a eficiência do uso da infusão de morfina intratecal, no tratamento da espasticidade. Método: Doze pacientes com espasticidade refratária a tratamento clínico foram estudados. Dez eram do sexo masculino e dois do feminino. A idade média foi 34,4 anos (20 a 61 anos). A média inicial da escala de Ashworth foi 4,6. Todos foram submetidos a implante de bomba de infusão para infusão Intratecal de morfina. Resultados: Ao final do tratamento o valor da escala de Ashw orth foi 2,2. A dose média de infusão intratecal de morfina foi $0,95 \mathrm{mg}$, com freqüência de aplicação de 1,8 vezes/dia. Como complicações, quatro pacientes desenvolveram prurido, dois náuseas, dois retenção urinária e todos melhoraram com diminuição da concentração da morfina intratecal. Um paciente foi submetido à revisão da bomba de morfina por extrusão do cateter. Conclusão: 0 uso de morfina intratecal para o tratamento de espasticidade refratária a tratamento clínico é eficaz e com poucas complicações.
\end{abstract}

PALAVRAS-CHAVE: espasticidade, morfina, infusão intratecal.

Spasticity is a motor disorder characterized by a velocitydependent increase in tonic stretch reflexes with exaggerated tendon jerks, resulting from hyperecitability of the stretch reflex as one component of the upper motor neuron syndrome ${ }^{1,2}$. Injured spinal patients with persistent increased resting motor tone (rigidity) and spasms have impairement of quality of life that had been under adaptation since the spinal injury. The spasticity can make simple and very important activities as use of a wheelchair impossible. Personal care, professional and leisure activities decrease a lot with spasticity. Spasticity treatment and control is imperative to improve the quality of life of spinal cord injured patients ${ }^{1-3}$.

The clinical treatment has been done with oral medications: diazepam, baclofen and dantrolene ${ }^{2-6}$. However, some patients are refractory to oral medications. Intrathecal baclofen infusion is very effective for long term treatment of spinal spas- ticity and is well known ${ }^{6}$, but it is very expensive ( $\$ 200.0$ dollars/month per patient) in Brazil. We need to work out with other alternatives to treat patients with spasticity refractory to oral medications. One option is the use of intrathecal morphine infusion. There are few reports in the literature about the treatment of spasticity by intraspinal morphine infusion ${ }^{4,7,8}$. Intraspinal morphine infusion does produce muscle relaxation, selectively in hypertonic motor segments below a spinal cord injury?.

The proposal of this study is the evaluation of the intraspinal morphine infusion in spinal injured patients with severe spasticity.

\section{METHOD}

Twelve patients with spinal cord lesion who developed spasticity refractory to clinical treatment were submitted to implant of morphine pump for Intrathecal infusion in the Functional Neurosurgery

\footnotetext{
${ }^{1}$ Functional Neurosurgery Division of University of São Paulo, ${ }^{2}$ rttopedic and Traumatology Institute of the University of São Paulo São Paulo, SP, Brasil. 
Division of University of São Paulo, from January 1997 to December 1999. The protocol was approved by the institution's Ethical Board. All patients signed informed consent. M inimum age for entry in the protocol was 18 years and minimum follow-up was 6 months. The spasticity was quantified by Ashworth scale. All patients were evaluated by multidisciplinary team with neurologist, neurosurgeon, orthopedic surgeon, physiatrist, physiotherapist, urologist and nurses. All patients were inicially treated clinically (oral baclofen $20-70 \mathrm{mg} /$ day, and diazepam 5-30 mg/day during 4 to 6 months). Patients with Ashw orth scale 4 or 5 who did not improve the Ashworth scale in 2 points after clinical treatment were considered refractory.

After clinical treatment failure, and the patients with Ashw orth scale of 4 or 5 were elegible to intrathecal morfine infusion by pump, 1 $\mathrm{mg} / \mathrm{ml}$ de solução, Initially they were submitted to the epidural trial phase. An epidural lumbar percutaneous catheter (Arrow, USA) was placed through level L4 or L5 and the catheter tip was located in the epidural space over T10. One milliliter of a solution of morphine sulphate was injected $1 \mathrm{mg} / \mathrm{ml}$ of solution 1 to 2 times a day. The patients used the epidural lumbar catheter for 1 week, and injected the solution 1 to 2 times a day. The patients and families were trained, under the nurse's supervision, for the morphine injection.

If the patients did not have any clinical complications with epidural morphine injection and had at least the Ashworth scale improved in 2 points, then the patient was eligible to the second phase of trial. The patient was submitted to morphine pump implantation. It was an Algomed pump (M editronic, Inc.-M inneapolis-USA).

The implantation was done under general anesthesia. Patients were positioned in lateral decubitus. A transverse incision was done over the end of the thoracic hibs and the subcutaneous was prepared to receive the reservoir and the set with the buttons. A catheter was placed in the intrathecal space by percutaneous approach from L4 or L5. The catheter was connected through subcutaneous space to the buttons set. The overall time implantation wasl hour. Patients were discharged from the hospital in the same day.

The reservoir is filled with morphine sulphate $30 \mathrm{mg}$ in $50 \mathrm{ml}$ of saline solution. Patient will use the pump initially one time a day $(0.6 \mathrm{mg} / \mathrm{ml} / \mathrm{day})$. The follow-up was done twice a month, and the morphine sulphate solution concentration was increased if necessary. If there were no side effects, and necessity to spasticity control, the concentration was increased up to $50 \mathrm{mg}$ of morphine sulphate in $50 \mathrm{ml}$ of saline solution. The patients were always informed about side effects. The results were monitored constantly, and if the patient developed any adverse reaction as pruritus, vomiting, dizziness, urinary retention, the drug concentration was decreased.

\section{RESULTS}

Two patients were females and 10 males. The median of age is 34.4 years (20 to 61 ys). Ten had injury localized in thoracic level, 1 in cervical level and 1 in the conus medullaris. Seven had complete spinal cord lesion. One of the etiology of injury was post operative tumor (ependymoma), 3 were by gun shot injury, 4 by traumatism and 4 was inflamatory ( 2 viral, 1 tuberculosis and 1 squistosomiasis).

The average time with spasticity is 4.7 years $(1,5$ to 9 years).

The Ashworth's scale initial average was 4.6 (4 to 5), and the final score was 2.2 ( 1 to 4 ). The median of dose concentration was $0.95 \mathrm{mg}(0.6$ to $1.1 \mathrm{mg} / \mathrm{ml})$ of morphine sulphate,
1.8 times/day (1-3 times). The follow-up range from 8 to 28 months (median 15.8 months).

As to complications, 4 patients developed pruritus, 2 nausea and vomiting, 2 urinary retention and 1 dermatitis over the skin above the implant. All patients were treated with the decrease of drug concentration and/or number of times injection per day. One patient had persistent headache with the use of intrathecal morphine, and asked to take off the pump after 8 months of use. One patient had skin damage and exposition of the pump, and it was removed and replaced after two months. One patient had treatment failure although the good result during the test phase and myelotomy was proposed. The monthly cost of morphine per patient was $\$ 10.00$ dollars.

\section{DISCUSSION}

The intrathecal morphine acts on the neuron of direct in the dorsal horn neurons, with inhibition of the motor neuron pool that causes the spasticity ${ }^{3,4}$. Segmental effects on the polysynaptic nociceptive reflex pathways are also likely to be involved ${ }^{8}$. The use of intraspinal morphine infusion is controversial in the literature ${ }^{2,9}$. How ever, it is an important alternative to treat patients with severe spasticity.

There are few reports in the literature over morphine infusion. Erickson et al. ${ }^{4}$ treated 4 patients with 1 to $2 \mathrm{mg}$ of intrathecal morphine injection. All patients had remarkable improvement in their spasticity score. Few complications were observed (itching and pruritus). Fenollosa et al. ${ }^{7}$ treated patients with chronic pain and spasticity after spinal cord injury and pain and spasticity improved with intratecal morphine infusion. No important tolerance developed after 3 years of follow-up, and only minor side effects were observed, and no one developed addiction?.

We treated 12 patients with spinal cord lesions, who developed severe spasticity refractory (Ashworth score 4 and 5) to clinical treatment with intrathecal morphine infusion. The patients had very important improvement in Ashw orth score (final Ashworth median score was 2.2). We also observed itching, pruritus, nausea, vomit and urinary retention, which could be treat by decreasing the morphine concentration. The patients did not develop any problem as tolerance or addiction. The baclofen for intrathecal use is very expensive in Brazil. The median cost for one patient is around $\$ 200$ dollars each month. The monthly cost of morphine per patient is $\$ 10$ dollars in Brazil.

The overall result was very good and the intrathecal morphine infusion was very helpful to control severe spasticity, and has only minor side effects.

\section{REFERENCES}

1. Lance JW. Symposium synopsis. In Feldman RG, Young RR, Koella WP, (eds). Spasticity: disordered motor control. Chicago: Year Book 1980;485494.

2. Young RR, Delwaide PJ. Drug therapy: spasticity. N Engl J Med 1981; 304:28-33.

3. Penn RD. Intrathectal baclofen for spasticity. In Gildenberg PL, Tasker 
RR (Eds). Textbook of stereotactic and functional neurosurgery. New York McGraw-Hill, 1998;1281-1286.

4. Erickson DL, Blacklock JB, Michaelson M, Sperling KB, Lo JN. Control of spasticity by implantable continuous flow morphine pump. Neurosurgery 1985;16:215-217.

5. Young RR, Delwaide PJ. Drug therapy: spasticity. N Engl J Med 1981; 304:96-99.

6. Penn RD, Savoy SM, Corcos D, et al. Intrathecal baclofen for severe spinal spasticity. N Engl J Med 1989;320:1517-1521.

7. Fenollosa P, Pallares J, Cervera J, et al. Chronic pain in the spinal cord injured: statistical approach and pharmacological treatment. Paraplegia 1993;31:722-729.

8. Coffey RL. Use of intrathectal drugs for spasticity. In: Gildenberg PL, Tasker RR (eds). Textbook of Stereotactic and functional neurosurgery. McGraw-Hill, 1998:1275-1280.

9. Hassnbusch SJ, Portenoy RK. Current pratices in intraspinal therapy: a survey of clinical trends and decision-making. J Pain Sympton Manag 2000;20:S4-S11. 